\title{
Religious Coping and Politics: Lessons from the Response to AIDS
}

\author{
Vera Silvia Facciolla Paiva ${ }^{1 *}$ \\ Departamento de Psicologia Social e do Trabalho da Universidade de São Paulo, \\ São Paulo, Brasil \\ Andrea Paula Ferrara \\ Mafoane Odara Poli Santos \\ NEPAIDS - Instituto de Psicologia da Universidade de São Paulo, São Paulo, Brasil \\ Richard Parker \\ Department of Sociomedical Sciences of Columbia University, New York, USA
}

\begin{abstract}
Religious coping with illness and the interactions among diverse forms of religiosity have posed challenges for the practice of health professionals, especially when sexuality is involved. What lessons can coping with AIDS offer? Based on archival research, case studies, workshops, and interviews, this article discusses the response to AIDS through the perspective of religious leaders who lived through its first decades in São Paulo, Brazil. Notions of solidarity, human rights, and ecumenicalism were articulated in the construction of the social response to the epidemic, including prevention efforts centered on condom use. These ideas expressed the historical period when mobilization for democracy post-dictatorship paralleled the AIDS crisis emergence. As in other religious traditions, "humanist-Catholics" in the government shared this perspective with their peers in the higher rungs of the Church, producing a "collaborative" religious coping style. In the Catholic responses, people with AIDS, including priests and seminarians, were cared for with the support from the Archdiocese, while the strained internal debate created opposition among "pastoralists" and followers of Liberation Theology and "canonists", especially in the field of prevention in which the Vatican delivered a discourse of a moral and "delegating" style of coping. Religious followers in whatever position - followers, clergy and authorities - produce and reproduce discourses on religious coping available in their socio-cultural and political contexts; its symbolisms remain implicated in personal coping - with cognitive, emotional and behavioral effects. Religious coping cannot be reduced to individual behavior and its relationship with dogma, the sacred and the transcendental. A broader comprehension of its psychosocial and institutional-political dimensions, as well as the interaction with the lived religiosity will enhance the research and the professional practice.
\end{abstract}

Keywords: Coping, religion, AIDS, institutions.

Endereço para correspondência: Departamento de Psicologia Social e do Trabalho, Instituto de Psicologia, Universidade de São Paulo, Av. Prof. Mello Moares, 1721, Cidade Universitária, São Paulo, SP, Brasil 05508900.E-mail: veroca@usp.br, apferrara@uol.com.br,mafoane@gmail.com ergp11@columbia.edu Agências de Financiamento: National Institutes of Health (NIH) /USA, Mac Arthur Foundation e Conselho Nacional de Desenvolvimento Cientifico e Tecnológico (CNPq). 


\section{Enfrentamento Religioso e Política: As Lições da Resposta à Aids}

\section{Resumo}

O enfrentamento do adoecimento e a interação com diferentes religiosidades são desafios para a prática profissional, especialmente quando a sexualidade está envolvida. Que lições o enfrentamento religioso da Aids poderia oferecer? Baseado em pesquisa documental, estudos de caso, oficinas e entrevistas, este artigo discute o enfrentamento da Aids nas primeiras décadas de epidemia em São Paulo na perspectiva de religiosos. Lideranças de várias tradições religiosas co-construíram a resposta social à epidemia, incluindo a prevenção centrada no uso do preservativo. Noções de solidariedade, direitos humanos e ecumenismo expressavam a mobilização democrática pós-ditadura paralela à emergência da doença. "Católico-humanistas" no governo compartilhavam essa perspectiva com seus pares da hierarquia católica, estimulando um enfrentamento religioso de estilo "colaborativo". Doentes com Aids, inclusive padres e seminaristas, foram acolhidos com apoio da Arquidiocese, enquanto acirrado debate interno opunha pastoralistas e adeptos da teologia da libertação aos canonistas (vaticanistas) que, desde então, disseminaram um discurso de enfrentamento de "estilo delegante" e moralista, especialmente no campo da prevenção. Religiosos em qualquer posição (fiéis, clérigos, autoridades) produzem e reproduzem discursos implicados em estilos de enfrentamento religiosos disponíveis em seus contextos socioculturais e políticos; seus simbolismos permanecem no enfrentamento pessoal - com efeitos cognitivo-emocionais e comportamentais. $\mathrm{O}$ enfrentamento religioso não pode ser reduzido ao comportamento individual e à relação pessoal com o dogma, o sagrado e o transcendental. Uma compreensão mais ampla das suas dimensões psicossociais e político-institucionais, assim como a interação do discurso técnico com a religiosidade viva, enriquecerão a pesquisa e a prática profissional na promoção da saúde.

Palavras-chave: Enfrentamento, religião, Aids, instituições.

\section{Afrontamiento Religioso y Política: Las Lecciones de la Respuesta al SIDA}

\section{Resumen}

Afrontamiento con la enfermedad y las interacciones entre diversas formas de religiosidad son desafíos para la práctica de los profesionales de la salud, sobre todo cuando se trata de la sexualidad. ¿Qué lecciones ofrece el afrontamiento con el SIDA? Basado en estudio documental, estudios de casos, talleres y entrevistas, este artículo discute la respuesta al SIDA a través de la perspectiva de los líderes religiosos que vivieron sus primeras décadas en São Paulo, Brasil. Las nociones de solidaridad, los derechos humanos y ecumenismo se articularon en la construcción de la respuesta social a la epidemia, incluyendo los esfuerzos de prevención centradas en el uso del condón. Estas ideas expresan el período histórico en el que la movilización de la democracia post-dictadura apareció paralelamente a la crisis del SIDA. Tal como en otras instituciones religiosas, "católico-humanistas", dentro y fuera del gobierno y de la jerarquía de la Iglesia, han producido un "estilo colaborativo" de afrontamiento religioso. En el campo católico, personas enfermas de SIDA, inclusive padres y seminaristas, fueron amparados con apoyo de la Arquidiócesis, mientras un intenso debate interno oponía a "pastorialistas" y adeptos a la teología de la liberación, a los "canonistas" y seguidores del Vaticano, especialmente en la prevención campo donde los "vaticanistas" diseminaban un discurso de afrontamiento moralista de estilo "delegante". Religiosos en cualquier posición - fieles, clérigos, autoridades - producen o reproducen discursos con estilos de afrontamiento religioso a la enfermedad disponibles en sus contextos socio-culturales e políticos; sus simbolismos permanecen implicados en el enfrentamiento personal - con repercusiones cognitivas, emocionales y de comportamiento. Estudios y prácticas profesionales en el campo del afrontamiento religioso se enriquecerían al considerar dimensiones que no pueden reducirse al comportamiento indi- 
vidual y a la relación con el dogma, lo sagrado y lo transcendental. Una comprensión más amplia de las dimensiones psicosociales, institucionales, y políticas, también la interacción con la religiosidad viva, enriquecerá la investigación y la práctica profesional.

Palabras clave: Afrontamiento, religión, SIDA, instituciones.

The increase in employment opportunities in the field of health care and social assistance expanded the horizon for the work of the psychologist. ${ }^{2}$ Recently, new practices developed in the field of basic medical attention and in contexts of highly complex hospitals, and psychotherapeutic and prevention models were updated (Centro de Referência Técnica em Psicologia e Politicas Públicas [CREPOP], 2008, 2009; Perucchi, Rodrigues, Jardim, \& Calais, 2011; Sampaio \& Araújo, 2006; Zurba, 2011). One of the challenges for professional performance in this context is the interaction of the religiosity of patients with that of health professionals.

In the academic literature about religion and psychology, two types of questions are most common: how do you consider or deal with the religiosity of patients in the area of psychotherapeutic practices, and what is role of religious behavior as a factor in coping with social contexts of illness (Faria \& Siedl, 2005; Peres, Simão, \& Noasello, 2007). The religiosity of health professionals and of religious authorities is still rarely explored in research, and in spite of the discomfort of people with firm religious beliefs when encountering psychological theories. ${ }^{3}$ It is an important gap in the academic debate the understanding of the religiosity dynamic of those who produce social and political discourses that give contextual meaning to religious coping as a psychologically embodied phenomenon (Garcia, Muñoz-Laboy, Almeida, \& Parker, 2009).

2 In Brazil, it takes place in the Unified Health System (SUS) and the Unified System of Social Assistance (SUAS) established since 1988 and 2005 , respectively, as public system that organize, in a decentralized way, the services of attention, vigilance, and prevention for health (SUS) and social assistance (SUAS).

3 The religiosity of psychologists and that of their patients is described as one of the motivations for students to approach the subject of the interaction of psychology and religion (G. J. Paiva et al., 2009).
In councils that oversee and regulate professional practice, on the other hand, the critical and conceptual reflection about the religiosity of psychologists flourished in parallel with the emergence of the AIDS epidemic and social movements that socioculturally and politically affirmed homosexual identity. The academic literature indicates that religious condemnation of homosexuality contributes to the production of stigma and discrimination of homosexuals, which, in turn, has been associated with major vulnerabilities to mental and sexual health problems in different cultures (Garrido, Paiva, Nascimento, Souza, \& Santos, 2007; Gough, 2007; Govender, 2011; Kian \& Anderson, 2009; Parker \& Aggleton, 2001, 2003). In Brazil, the resolution of the Federal Council of Psychology (Resolution CFP No. 01/99)expressed the debate around these findings using a human rightsbased framework, which has been frequently invoked in response to AIDS and has advised against therapeutic practices that aim to cure homosexuality or that contribute to the discrimination of non-heterosexuals.

The field of HIV/AIDS prevention and care has lessons to offer. The effectiveness in this field has depended on technical innovation to work with the interaction among different forms of religiosity, which requires respect for the diverse lifestyles of health services clients and challenged professional practices strongly marked by personal values. In the promotion of condoms, care for the ill, in primary care or in the area of social assistance, the responses of health professionals to the epidemic stimulated the revision of theories and techniques used in university courses, especially in the field of sexuality (Parker, Garcia, \& Muñoz-Laboy, 2013). These responses also validated the human rights perspective in health-related professions (Gruskin \& Tarantolla, 2008, 2012; V. Paiva, 2008).

These challenges are not limited to the Brazilian context. Discussing a global panorama of 
the epidemic in its second decade, Mann and Tarantola (1996) included religion as an important factor to consider when discussing social vulnerability. They understood that for a large portion of world religion gives meaning to life, birth, marriage, suffering and death. Religious leaders create norms that regulate sexuality, they become involved in politics and in lawmaking, as well as in educational programs, in medical institutions, and they affect the culture of health and illness. The authors questioned if health professionals should fear religious interventions, or if they "should they consider religious leaders and morals allies in the context of AIDS?" (Mann \& Tarantola, 1996, p. 447). As Defert (1996) discussed, programs in various countries addressed sexuality, stigma, and condom use in a secular manner and have not found a simple answer to this question.

If we take the period of the emergence of HIV/AIDS as an example, we can observe different public manifestations of how religious institutions have confronted the crisis of the epidemic since the 1980s. Religious leaders and institutions are known throughout the world for their efforts to mobilize solidarity and care for persons affected by the epidemic (Garcia \& Parker, 2011; Sanchez \& Nappo, 2008). On the other hand, whereas some religious leaders, family members, and officials from various areas of health responded to the need to control the pandemic and mitigate the physical and mental ailment of those who were ill, many political leaders and health professionals exacerbated the stigma and discrimination associated with HIV based on their personal faith - from church pulpits, working in public health services, and even in universities (Farmer, 1999; Galvão, 1997; Garcia et al., 2009; V. Paiva \& Zucchi, 2012).

In Brazil, the AIDS epidemic and the democratization movement emerged during the same historical period (Berkman, Garcia, Munoz-Laboy, Paiva, \& Parker, 2005). In 1988, the Brazilian Constitution guaranteed governmental actions that ensured religious liberty and the secularity of the state, as well as the right to universal access to integrated health care, including prevention and rehabilitation. Over the next two decades, governmental politics and prevention programs centered on condom use were largely accepted, even though a large majority of Brazilians declare themselves Catholic and the Vatican has been against condom use ${ }^{4}$ (V. Paiva, Aranha, Bastos, \& Grupo de Estudos em População, Sexualidade e Aids [GEPSAIDS], 2008). How should we interpret this social, cultural and political context as it affects psychological outcomes?

Social scientists working on religion in Brazil highlight that personal and day-to-day dimensions should be considered in documenting the history of religion (Burdick, 1996; Chesnut, 1997). They describe how the dynamics of religious affiliation, the private ethos, and the individual agency of the religious subject are frequently challenged by daily life (Duarte, 2005; Watanabe, 2005). These dynamics have produced polarization in reaction to the epidemic and are an integral part of the "Brazilian response to AIDS”.

\section{Religious Coping}

In the field of the psychology of religion in Brazil, G. J. Paiva (1998, p. 28) brings to our attention the literature on stress and coping in the context of the relationship between health, religion, and HIV/AIDS, especially expanding on the work of Pargament ${ }^{5}$ who defined coping as a process of dealing with important personal and situational demands, a psychosocial phenomenon that the emergence of AIDS mobilized.

Researchers of stress and coping were the first in the field of psychology to focus on people affected by AIDS, before the existence of antire-

4 A national household study observed that education about condom use in schools for students older than 15 years was strongly supported by those of all religious affiliations - by $94.5 \%$ of Pentecostals, $98.5 \%$ of Catholics, and $100 \%$ of members of Afro-Brazilian religions. This study also showed that $83 \%$ supported making condoms available for adolescents in schools and 94\% supported their availability in health posts (V. Paiva et al., 2008).

5 Pargament, K. I. (1990). God help me: Toward a theoretical framework of coping for the psychology of religion. Research in the Social Scientific Study of Religion, 2, 195-224. 
trovirals (Coates, Temoshok, \& Mandel, 1984; Vasconcellos, 1992). Among the most important aspects of evaluating situations that require coping is the process of attributing an origin (cause) to the distressful event and identifying the reactions to this event. The literature on religious coping in situations of stress - notably resulting primarily from studies on Christiansabundantly describes how causes of events, particularly negative ones, are attributed to God, and how people remain passive and God is seen as an active agent.

Quite sophisticated, the theory of coping with stress is dedicated fundamentally to studying the context of chronic illness, as HIV and AIDS are often framed today in places where antiretrovirals are available. The process of coping described in the literature includes repercussions on the cognitive, emotional, and behavioral levels. Scholars using this theoretical framework that are strongly positioned in social psychology: having an understanding that coping is influenced by culture, modeling situational evaluations, and positing that the "system of people's orientation in the world and their coping strategies" could be "taught and privileged in a sociocultural context, to the detriment of others" (Faria \& Seidl, 2005, p. 383). The functions of religion in coping and problem resolution depend on the style of coping adopted by the person, on how responsibility is attributed, and the extent to which the person willfully participates. In the self-directed style of religious coping with stressful events, the responsibility of coping with problems is placed on the autonomous individual, without transcendental reference. In the delegating style, the solution is left to the divine sphere, frequently "in the hands of God". The collaborating style draws on the participation and responsibility of the individual as well of the divine (Faria \& Siedl, 2005; G. J. Paiva, 1998).

This article will address religious coping through the perspective of the religious leaders that participated in the first years of constructing a social and psychosocial response to AIDS in São Paulo and in various institutional positions, particularly focusing on Catholics. We describe the ways in which they expressed their religio- sity in the advent of the epidemic while they interacted with a governmental response to AIDS, which was based on evidence produced in the fields of epidemiology, infectology, preventive medicine, among other disciplines.

In this article, were refer more to religious leaders than to their followers, utilizing the notion of religiosity described by Faria e Siedl (2005), conceived as a primary adherence to beliefs and practices of an organized religion, with personal and institutional aspects. As we will show, this historical account can inform new research and psychosocial intervention practices that interact with religiosity - a psychological phenomenon inextricably associated with its social, cultural and political context.

\section{Methods}

The data analyzed in this project was collected in the context of a multi-site study ${ }^{6}$, which had the general objective of understanding how institutions from Christian and Afro-Brazilian religious traditions conceived AIDS and the ways in which they positioned themselves to participate in a social and political response to the epidemic.

The methodology for the discussion that follows was designed based Burawoy's model for ethnographic research (2009) known as the "extended case method", which combines participant observation and historical analysis based on observing diverse moments across time. This type of analysis also allows for an understanding of how political and structural forces interact. A pre-analysis of documents (e.g., available media, government reports, from organizations, and

6 This article was based on data collected in the study "Religious Responses to HIV/AIDS in Brazil". The national study was coordinated from 2005 to 2009 by Richard G. Parker and took place in four cities: Rio de Janeiro (coordinated by Veriano Terto Jr.), Porto Alegre (coordinated by Fernando Seffner), Recife (coordinated by Felipe Rios), and São Paulo (coordinated by Vera Paiva). Additional information about this project can be obtained at http.abiaids.org.br, the website of the Brazilian Interdisciplinary AIDS Association. 
academic literature) was fundamental for the selection of key informants interviewed in the research process.

In the case analyzed here - the religious responses to AIDS in São Paulo in the first two decades of the epidemic - the first research activity was a group interview organized as a workshop for debates among religious leaders from the three religious traditions we focused on-Catholic, Umbanda-Candomblé, Evangelical Protestant - along with health professionals from AIDS programs that participated in various moments in the religious response - including psychologists, medical doctors, and social workers. A "time-line" produced collectively was the primary result of the personal testimonies on how each narrator coped with the AIDS crisis and debates about this social history of the epidemic in São Paulo. ${ }^{7}$ In the initial part of the workshop, groups were separated according to religious tradition, and later in the day we gathered an interreligious group setting to construct a sole narrative and reflect critically about it.

The analysis in this article is also based on the narrative of 78 in-depth interviews, which took place from 2005 to 2008 . All of those interviewed - priests and priestess of Afro-Brazilian religions, Pastors, priests, chaplains, members of religious social organizations, activists from the STD/AIDS Pastoral ${ }^{8}$, catechists, and health professionals from AIDS programs - were directly involved in the governmental and non-governmental response during the first years of the epidemic in São Paulo.

For this analysis, we drew significantly from data collected as a case study of a non-governmental organization (NGO) founded in the 1980s,

The result of this activity is published in Souza, Santos, Almeida and Paiva (2012) and it is translated to English and Spanish.

8 The variety of "Pastorals" that carry out the bureaucratically structured social work of the Catholic Church in Brazil deliver particular responses to social problems related to the family, youth, children, marginalized women (often a euphemism used to describe for sex workers), blacks, among others. There is specific Pastoral dedicated to AIDS, which is located in Porto Alegre (see for example, Seffner et al., 2008). where we conducted archival research and interviews with coordinators, staff, and clients.

The historical leaders interviewed, some were elderly when interviewed, also provided primary historical documents that were used in this analysis. Among the documents analyzed for this text, we highlight the minutes of the AIDS and Religion Working Group from the State STD/AIDS Program of the state of São Paulo as well as documents accessed at the Archives of the Metropolitan Chancery and Library of the CNBB in São Paulo.

All of those who were interviewed and partook in data collection group activities signed an informed consent form before data was collected through audio-recordings that were transcribed. The project was approved by the National Commission for Research Ethics (CONEP) of the Brazilian Ministry of Health.

The framework for this analysis is the social approach to address health in a constructionist and human rights-based perspective (V. Paiva, 2012a, 2012b). Utilized and globalized in the context of the global response to AIDS (Gruskin $\&$ Tarantola, 2008, 2012) the human-rights based perspective of vulnerability (individual, social and programmatic) to understanding health and illness emphasizes a "social history of disease" rather than a "natural history of disease". This is not only important because it is impossible to think of the processes of health and illness as of independent of cultural, historical, structural determinants, but also because a social perspective is a way to convey this history (Ayres, Paiva, \& França, 2010, 2012).

In revisiting the social history of AIDS based on the narratives of the religious leaders analyzed through this conceptual lens, this text sets out to broaden our comprehension of religious coping, which will not be discussed solely from an individualist and behavioral point of view.

\section{The Context of Responding to the First Cases of AIDS in São Paulo}

Every year they prepare a liturgy to pray for the victims of AIDS. What's the point? They are already with God, they don't need your 
prayers anymore... In the beginning, we had in São Paulo Dom Paulo [Archbishop], and he was in favor of condoms, with his theory that "among evils, pick the lesser evil". Supported by many religious people, many bishops, priests. I personally always said: if it is to prevent, to preserve life, it is not a greater evil, but it is a greater good. We should always seek for ways to defend life and do all we can to defend it, using all means that our intelligence allows us to be able to live a life of plenty. That is what Christ thought, the thought of the Gospel. "I came so that all could have life, and have plenitude". (Priest, interviewed in 2006)

Several factors contributed to the prompt response of the state of São Paulo to the epidemic and to the organization of what would become the first AIDS program in the Americas in 1983. The city of São Paulo, beyond being the center for business and the industrial capital of the country, was home to a synergy of social movements resisting the dictatorship since the 1970s: students' movements for democratic liberty, labor union movements for dignity in work settings ${ }^{9}$ in addition to the homosexual movement and movements of women against poverty in coalition with the feminist movement.

Contemporary to the first cases of AIDS, the so-called "detente policy" of the military governmentall allowed, after two decades of dictatorship, the election of local governments by popular vote. The governor elected in 1982, Franco Montoro, a Philosophy professor and adept of the humanist-Catholic movement, was different from other Catholic political leaders and conservatives put in place by the military in all of Latin America. The humanists defended the "dignity of the human person" in various social movements. In taking posts as government officials, they frequently made references to the Universal Declaration of Human Rights of 1948, to the "ethics of solidarity", and to the principle of "participation" and to the promotion of citizenship "that was not only having rights, but

9 Led by Lula da Silva -who was the President of Brazil from 2002-2010. developing consciousness and social responsibility" (Pollozi \& Souza, 2001, p. 13).

This state government welcomed an almost immediate response to the first cases of AIDS in 1981-82, and the health professionals who headed this response had participated in the sanitary reform movement since the 1970s and at this point acted as public servants in the State Health Secretariat and in the municipalities that were most affected, defending the universal right to health. At least one year prior to the formation of the National AIDS Program, this political scenario produced the first Brazilian non-governmental organization (NGO) dedicated to persons affected by the epidemic (Support Group for AIDS Prevention - Grupo de Apoio a Prevenção à Aids [GAPA]), which was also organized by health professionals from the State Health Secretariat of São Paulo and by leaders from the homosexual rights and human rights movements.

The testimonies of key informants that participated in that moment indicated that, early on, many religious leaders sought information reacting to cases of AIDS in their churches, in their terreiros (Afro-Brazilian place of worship), and in their Spiritist centers. These religious leaders opted to not exclude people with HIV in their communities, and they sought health professions with the objective of becoming informed by the technical-scientific discourse. Most of these religious leaders had a prior history of work with social problems: they were Catholics who came from the Ecclesiastic Base Community Movement ${ }^{10}$ on behalf of social justice and health, pro-

10 The Brazilian Catholic Church "played a key role in the articulation of civil society, in defense of human rights, of democratic liberties, of agrarian reform, on worker's rights and of redemocratization" (Azevedo, 2004, p. 112). The relationship between the Roman Catholic Church in Brazilian political culture makes this institution and its initiatives particularly important in the study of contentious politics against the dictatorship. The grassroots social movements related to the Church were carried out primarily in Ecclesiastic Base Catholic Communities (Comunidade Eclesiais de Base), which provided spaces for mobilization and network formation. These spaces 
testants with the Ecumenical Movement and the fight for Human Rights, and members of Afro-Brazilian religions that fought against religious intolerance and in favor of a culture of peace.

In 1985, with support from the State STD/ AIDS Program in São Paulo, religious leaders from Afro-Brazilian religions produced a manual of how to use ceremonial blades and scissors in safe ways, seeking to guarantee the continuation of their rituals, being accused of disseminating "bad things... this time, of spreading the AIDS virus". In 1986, the Special Group for Culture, Candomblé and AIDS (GECAIDS) was organized when dozens of priests of this religious tradition were among the sick and dying of AIDS.

Among Protestants and evangelicals, people with a history of fighting for democracy and social justice attempted to include AIDS in its battles focused on "overcoming poverty and classist exclusion". Those interviewed recounted the difficulties of placing the issue of AIDS on the agenda of the World Council of Church in a significant way until 1995 because many people affected by the epidemic did not fit into their definitions of exclusion at the time.

São Paulo has been the Brazilian state most affected by the epidemic, and it counted with the social and political capital of leaders who fought for democracy and the possibility of innovating a response informed by the technical-scientific knowledge generated in its health programs and universities.

In the Catholic field, the Archbishop of São Paulo, Dom Paulo Evaristo Arns, was referred to unanimously by our informants as an important

and the involvement of Catholic elite leaders were key to confronting the dictatorship in the 1970s-1980s (Azevedo, 2004). Progressiveness depending on the local orientation of groups and leadership, following the emphasis of grassroots involvement, individual self-esteem building, emancipation, and the ownership of social problems and solutions expounded by Liberation Theology (Burdick, 1996). The differences between conservative discourses and progressive local actions supports the differentiation made by Azevedo (2004, p. 111), arguing that the hierarchy of the Church in Brazil has more "symbolic authority" (autoridade simbólica) than "disciplinary authority" (autoridade disciplinar). source of support. Ordained Cardinal in the harshest years of the dictatorship, he welcomed and included followers of "Liberation Theology" (LT) who fought for an end to political torture and the establishment of democracy (Gaspari, 2002). This was not the attitude of all of the Catholic Church, which polarized the response to AIDS (Galvão, 1997; Parker \& Aggleton, 2003). As discussed by Mott (1985), on one extreme you had the Cardinal of Rio de Janeiro Dom Eugênio Sales, uncompromising, accuser of those who were sick, and on the other, you had the "most magnanimous Cardinal of São Paulo", who stressed his mission to comfort people with AIDS like all who were gravely ill.

The inclusion and care (acolhimento) of the ill, motivated by health officials, took place from the outset in terreiros of Afro-Brazilian religious traditions, which were more open to homosexuals strongly affected by the epidemic. Many religious leaders echoed resistance to the military regime on behalf of democracy and supported the non-governmental response, and not without opposition and barriers, the government provided them with technical and financial resources. One physician, who actively participated in the construction of the first AIDS program in Brazil, recalled that it was possible to find respect for human rights and solidarity in the attention dedicated to illness and death with dignity. Health professionals, including many psychologists from the AIDS program, valued humanism among Catholics in government and those that acted through the rooted networks (capilaridade) of the Archdiocese. Based on the notion of "ecumenicalism" and "solidarity," religious leaders and health programs co-organized prevention and care activities that helped diminish stigma associated with the illness.

The first year that World AIDS Day was organized. We had an ecumenical ceremony in the Cathedral, with Dom Paulo and other religious authorities, from Candomble, and with a Jewish Rabi, who involved himself very early on, as well (Public health physician).

The health professionals interviewed recounted the ways in which groups of Catholics, Evangelicals, and Protestants that shared in the 
inspiration of Liberation Theology "moved very quickly in São Paulo for the reduction of stigma and discrimination with a more progressive attitude". The same was observed among religious leaders from Spiritist and Jewish groups, and priests of Umbanda and of Candomblé who were invited to participate.

Assistance and support for people with AIDS, still without treatment available, was the focus of religious leaders in the first decade of the epidemic. The topic was treated with discretion, surrounded by secretiveness, but was not denied. According to the testimony of one elderly priest, the first cases of priests and seminarians with AIDS in the mid-1980s were treated with care and solidarity:

It was 1988... An older woman, 72 or 73 years old, in a meeting of the Pastoral expressed herself with respect to AIDS: "Father, this disease that priests get...?" [laughter] ... What I want to emphasize is a situation marked by confusion. It was not a well-understood sickness; there was an enormous fear because people died in a short period of time, and so people had a lot of reservations... A human and Christian response is solidarity. This was imposed, you see? Thank God, we no longer had those restrictions. Like they say, the criticism of certain behavior in Catholic morals does not take away the dignity of the person. (Priest who was active in the Health Pastoral)

Solidarity was, nonetheless, almost always regulated by the norms of the religious communities that sustained it. Some adjustments to the religious principles of the congregation, the church, the temple or the Afro-Brazilian terreiro were necessary so that care and support could be offered. Rules of silence were common, for example, and the reclusion of members of the religious community was the case especially among religious leaders living with HIV but much less common for followers of Umbanda and Candomblé, according to the interviewees.

Another interviewee, who was a vicar for nine year, narrated his first contact with the illness and "death of two colleagues" in the mid-1980s. The first was a seminarian who, when he developed AIDS, was able to resist without asking for help, locked in his room. The interviewee recounted how shocking it was to see him for the last time before he was interned. The vicar had heard nothing else until he found out the seminarian had died. The question of "he died of what was only for a select group of close friends... everything was awkward at the time and without much sentiment of solidarity". The same interviewee defined the second case as a suicide, "an exit" to the situation. "He crossed a busy avenue without the precaution, and he was still alive when taken to the hospital. A priest that lived with him said he heard the doctors commenting that he had AIDS".

Interviewees from all religious traditions agreed that the option of silence was due, in the first place, to the insecurity of the modes of transmission to avoid panic in case people found out that they welcomed people with AIDS. The association of the epidemic with promiscuity and being known as "gay disease" also created discretion. As one priest remembers:

Facing insecurity, few people were disposed to welcome and care (acolher) for carriers of the virus. At that moment, Dom Paulo had a lot of psychological influence: We cannot stop carrying for people, and it is not because we do not approve of homosexuality that we are going to stop treating those people.

Interviewees agreed that a large part of those who immediately became involved in efforts against AIDS were mobilized by the history of having known someone affected by the disease. Institutional mobilization happened gradually, and it was stimulated by the notions of "solidarity" and "compassion". The narratives of those interviewed and the documents analyzed trace parallels in the priesthood and the "caregiver of souls", "pastor", and the notion of "acolhimento" of those in suffering; in the first years of the epidemic, to help them "deal with death" and "die with dignity". At the same time, more politicized initiatives used the notion of the protection of rights. Many narratives compared the activities of religious leaders to those of integral assistance in health care, conceived as "care for the body, the soul, and of citizenship". 
Under the orientation of, or more precisely, with a "call to action" from health professional at AIDS programs by the end of the 1980s, members of Afro-Brazilian religions and Catholic organized the first halfway houses for children and adults living with AIDS, who, rejected by their families were welcomed there. Evangelical groups with houses to intern drug users took on work to welcome the ill with that profile. In other words, health professionals, religious followers and others not belonging to any religion, began to dedicate themselves to prevention and actively sought religious leaders to extend the reach of their work. The "Religious Group for Education, Support and Solidarity" was formed as an "ecumenical group," which brought together different religious tradition to plan the actions of and capacity building among religious leaders of diverse traditions. In 1988 and 1989, the Center for Training and Reference for AIDS in São Paulo brought together priest/priests of Afro-Brazilian religions, Lutherans, Presbyterians, Catholics, Jews, Mormons, and Kardecists in workshops, talks, in the production of booklets and other educational material with language appropriate for each religious tradition. Catholic and Evangelical Protestant leaders were slower to taken in the area of prevention.

In sum, the first decade of the response to AIDS, organized by the state in collaboration with civil society, was able to forge a scientific debate together with religious leaders, made it possible for the dissemination of correct information, and diminished discrimination for people living with HIV. The notion of solidarity and the rights perspective is exemplary of the concretization of health reform in the state in the direction of guaranteeing universal and integral health care, even before the Unified Health System (SUS) existed. They worked with the religiosity of those who confronted the epidemic in a collaborative way along with health authorities. This discourse of religious coping stimulated among religious followings a collaborative rather than a delegating style of coping.

At the end of the second decade, the intimate partnership between the State STD/AIDS Program and religious groups was restricted to isolated and sporadic initiatives. As discussed by Souza et al. (2012), because of the political pressure from followers of Afro-Brazilian religions and a new generation dedicated to health promotion among the black population in Brazil, a Religion and AIDS Working Group was organized in 2002. The notion of "inter-religiosity", a technical innovation, substituted the notion of "ecumenicalism", redefining spaces and activities with greater emphasis on prevention. The Catholic presence - which minutes from meetings helped to clarify - was much rarer than in the beginning of the epidemic. The following section clarifies the production of this situation.

\section{The Catholic Response in São Paulo: Pastoralists vs Canonists}

Several Catholic interviewees mentioned a significant number of priests dying of AIDS in the first years of the epidemic, many coming from other regions of Brazil to São Paulo. The numbers mentioned by the interviewees vary, but they consistently cited approximately 50 religious leaders with AIDS. A priest who lived through this period narrates the first case.

He was the first priest who died of AIDS here in São Paulo. He was professor before he entered the seminary, and he was interned in the hospital. . . I I can speak of the nun who must have taken in more than thirty cases, you see? ... There is one being cared for until today who is 83 years old... I made sure to maintain a form of contact that was normal, human, friendly and with fraternity. [He was] young! Called the attention of the archbishop and of the Health Pastoral of the Archdiocese. He was interned in a public hospital, and the reaction of its health professionals was very reserved, very fearful, in a way that the priest did not last very long, died quickly; that's what happened in all of the first cases. And, at the funeral not many people came close to the coffin; in fact, the coffin was sealed. When it was time to bury him, the man from the funeral refused to take the coffin from fear of contagion. And the family was really profoundly shocked. But at the church he was welcomed 
and cared for (acolhido), accompanied normally. This was the first case. (Priest from the Pastoral)

The Catholic pastoralist authorities, as mentioned by the interviewee above, preferred collaborative and "ecumenical" action, in "solidarity" with other religions for the common good. They encouraged "charisma" in social action, organized ecclesiastic base communities (CEBs), the mobilization of thematically organized pastorals (of work, of health, among others) to disseminate the principles of participation in solidarity. A collaborative style of coping with the emerging epidemic was one of their fronts of action.

That movement was not as active in all places. The religiosity of more conservative Catholic authorities was slow to respond to AIDS as a specific issue, the debate over the mission to evangelize was the key issue. As Galvão (1997) discussed, they dealt with the resurgence of catechizing to tackle the increasing actions based on Liberation Theology (LT), while they were confronted with the growth in evangelical groups throughout the country. They organized the charismatic renovation movements to reach followers with effusive songs, with faith healing rituals, and the use of radio and television channels granted by the state, which until today are inaccessible to non-Christian religions. Interviewees noted this alignment of the Archbishop in Rio de Janeiro with the official position of the Vatican of John Paul II. Other more canonic Catholics with conservative positions about the epidemic as well as many physicians who dealt with the emergence of AIDS in this period, as something restricted to the moral universe, or related to divine punishment, adopting a discourse that could be considered as a delegating style of coping.

On the other extreme were Liberation Theology (LT) supporters. This religious movement brought together diverse Christian theologies that emerged in Latin America, as one of the priests interviewed described it. As Perea (2004) discussed, many of liberation theologians were accused of fomenting the formation of "communist cells within the Church" because they organized ecclesiastic based communities using the logic of the first Catholic communities, which was associated with socialism by opponents of
Liberation Theology. Integrated in the Christian faith, CEBs concentrated on the situation of poverty and social inequality resulting from economic structures and social injustice and on a theology that "conceived people in poverty and need not as an object of charity, but as subjects of solidary liberation from their need". Their religiosity was dedicated to social change and a pastoralist mission, which "implies being together with the people". One interviewee defined the canonists religiosity as one "linked to the canonic right of Church, which resists renovation", a preference of the politically conservative governments in Latin America.

These two extremes represent, on one hand, the official position of the Vatican, canonic and hegemonic in Rio de Janeiro, and on other hand, and unofficial position that prevailed with relation to the semi-institutional and diverse sectors of the Church and governmental response to AIDS that took place in São Paulo (Murray, Garcia, Muñoz-Laboy, \& Parker, 2011).The resistance to a position that was more canonic and official was also justified by several interviewees, based on the specific mission of each congregation, as in the case of the Camilianos - a congregation dedicated to the ill - which cared for priests and seminarians with AIDS or acted together with the ill in chaplaincies at public hospitals. ${ }^{11}$

11 For those not familiar, the hierarchal structure of the Church is centralized around the Pope who creates rules through official documents (such as encyclicals) and directs a college of bishops who have jurisdiction over the members of the Church according to territorially-defined dioceses, which include priests (parish priests and vicars) with roles in a determined location or parish. The archdiocese is an important diocese, because of size and historical reasons. The way the structure functions, however, allows for the aggregation of different missions. For example, distinct congregations (Camillians, Franciscans, Jesuits) organize the education of religious followers and leaders according to their specific mission as actors in civil society more broadly. The mission of a congregation goes beyond the rituals shared by all Catholics (Sunday mass, the rosary, holy days, baptism, first communion, confirmation, marriage, last rites). 
The religious congregation that I belonged to establishes that members of this Order should be disposed to give their lives to assist persons affected by infectious diseases. [That was] my position when faced with the new disease that appeared in São Paulo . . . among the first cases was a priest infected with HIV. (Camiliano priest)

Priests and pastoral agents that worked with children and homeless adults, in contact with sex workers and drug users, especially in shantytowns, disseminated information about the illness and prevention in their social and parochial actions. The majority of them had already "witnessed the ailment and isolation" of persons living with AIDS. Many of these activists and volunteers went to, or invaded, the offices of the Secretariat of Health demanding "more hospital beds" or conditions to offer palliative care and "dignity" to those who became sick and died. ${ }^{12}$

Linked to the hospital context, I tried to create a unit for assistance for children with HIV in the children's clinic. The board of directors strictly refused. They said that if children with HIV were interned, the population would no longer intern more children in the clinic. (Priest and chaplain)

Because they participated in the democratic resistance against the dictatorship, ecclesiastic base communities acquired a political repertoire to comprehend the principles of the secular state established in the constitution in 1988. According to several interviewees, progressive Catholics active in various structures of the Church, in NGOs or in the government, contributed to broadening a respect for freedom of faith and even of sexual orientation in spaces where public policies were made. Religious and governmental actors conceived participation in the following way: "in consulting and in the involvement in work at the grassroots in the mobilization and the proposition of local actions, at the same time, increase citizenship and promote emancipation". AIDS Programs from various municipalities also accepted financial assistance from

12 http://www.forumAIDSsp.org.br/publicacoes ed2/assistencia.htm (Accessed 20 May 2009). non-governmental organizations with a public budget, based on the principle of participation and decentralization, a practice that was maintained in the third decade of the epidemic (Garcia $\&$ Parker, 2011).According to the interviewees, the halfway houses (casas de apoio) organized during the following period and the NGOs dedicated to coping with the epidemic, initiatives of pastoralist religious leaders emerged "due to necessity". In a period when the Unified Health System did not exist yet, and hospitals were slow to react adequately, the Health Pastoral created incentives for volunteers to mobilize "each in his/her own way", supporting autonomy. One of the founders of the AIDS program in São Paulo explained:

When the project for halfway houses (casas de apoio) was presented along with the candidate institutions, there were many reactions... "Wait just a moment, what is that? A priest of an Afro-Brazilian religion [a coordinator of a half-way house], that's not possible!" But the [government] authorities ended up agreeing. The question followed: how are you going to distribute the money? This was not the first discussion. We managed to get the first contract in 88 for distributing money from the state of São Paulo. [There were] many discussions with the judicial sector, as with the politi$\mathrm{cal}$, [in which opponents] made it clear that it was absurd to make a contract with a transgender woman (Brenda Lee) who has a (halfway) house where sex workers lived. [In that context...] The Church should be seen as any other civil society organization with initiatives to provide support, reduce the social impact, and cover that which the State could not or was not able to provide. (Public health physician)

The collaboration of the State with the Catholic Church was, since then, strongly based on the notion that the Church "can reach various places where the public or even the private sector cannot, right?" as an activist from the AIDS Pastoral recalled in an interview, an argument that was made repeatedly in other states in Brazil (Garcia, Muñoz-Laboy, \& Parker, 2011; Murray et al., 2011). Supported directly by the Archdio- 
cese of São Paulo or by missionaries, halfway houses were open for adults and children living with HIV, especially those in most need "from a socio-economic point of view"13 - a form of political economics used to interpret oppression and solidarity. Valued by interviewees from all religious traditions, the Archdiocese of São Paulo in that period left a legacy of a not-for-profit social organization in defense for the rights of people living with HIV, welcoming and caring for people of all religions. Twenty-five years later, that organization still worked in the field of health, in education against discrimination based on sexuality and gender, providing legal assistance, and distributing food.

Many of those interviewed told the story of the Franciscan friar with HIV who, when he assumed a homosexual identity, founded an NGO.

The friar wanted something more technical and scientific. He wanted a line of work that valued the person with HIVIAIDS as a human being, who did not have death as the only path for a life of suffering. The greatest concern for him was not to increase stigma within the seropositive person of being someone who is "socially dead". He wanted to bring him back to life... The Center emerged in a time of panic. Then we had strong work in education, politics . . . At first, we acted as representatives of the person with HIV. But, after a certain time... The person living with HIV should be a protagonist in his own life... his rights, occupy spaces that fit him, that he deserves. (Health professional at the NGO)

Created and supported by Franciscans, the organization played an important role in the non-governmental response. Through time, employees at the center demanded overcoming the framework of benevolence, and called for the creation of disseminators ("multiplicadores") and protagonists who occupied a place next to the public power. It can be observed that, as in the case of specialized health services for AIDS, users who were once rejected and stigmatized

13 http://www.alivi.org/Alivi/quemsomos.htm (Accessed 20 May 2012). treated the space as an extension of their home, regardless of his/her personal creed. A social worker insisted in her narrative that the religious leader began to say, "Look, we are not the ones that need to take care of your life, but you are the one that needs to direct your life and not the institution".

The quinquennial report (1985-1989) of the Archdiocese of São Paulo to the Vatican, for the first time included "pastoral action in response to AIDS." In one excerpt, the report includes a project of the Church in São Paulo:

In the last years, São Paulo became the center for people with AIDS in Latin America. The Church of São Paulo did not omit itself from this field. It developed extensive work of public awareness of the severity of the disease, its transmission routes and how to prevent its spread. It promoted and participated in debates and days of study on various levels, including those of ecumenical character. Parish priests and other church institutions were encouraged to give their collaboration. (Arquidiocese de São Paulo, 1990, p. 103)

It was in this historic period that LT was condemned twice by the then Cardinal Joseph Ratzinger ${ }^{14}$, leader of the Congregation of the Doctrine of Faith. In 1989, papal action diminished the territory of the Archdiocese of São Paulo, dividing it into four dioceses. Those interviewed were unanimous in affirming that the position of Dom Paulo and his ecclesiastic base communities responding to the AIDS epidemic was the turning point that led to the decision to divide the diocese that was under his responsibility. The social religious organizations and "the church of the base" were leaders in a movement for transforming religiosity, in a network with other organizations that were learning and comprehending how to deal with the epidemic.

This was when the debate about prevention and the use of condoms began to take shape, and the Vatican expanded its political action in the field of AIDS. The scene witnessed by the octogenarian priest is striking:

14 Later Pope Benedict XVI. 
I do not remember the year... in the first congress about AIDS in the Vatican an African priest with AIDS was there, and the presiding Cardinal made him leave the room. Then there was a reaction [against the expulsion], and he called him in. At that same congress, the now Cardinal $[\mathrm{X}]$ said that if in a couple one of the people had AIDS, and the couple wanted to continue having sexual relations that one of the two should be disposed to getting AIDS, but that they should not use condoms. (Priest active in the Pastoral)

While religious leaders, program managers and states were still denying the priority and emergency of the epidemic, producing a discourse of delegating or moralist coping, the programmatic vulnerability of those most socially vulnerable increased. That is how the more canonist line entered the debate over prevention.

\section{The Controversies over Condoms: "It has Less Holes than the Holes in Monogamy and Fidelity Among Couples"}

A context that was less common in other countries, the dialogue between the government and civil society in the first decade of the epidemic included diverse organizations of the Catholic Church that recognized the contribution of science and of the ethical-political benchmarks of sanitary reform. Many of those interviewed recalled the initiatives of the $\mathrm{CNBB}$ at the time, which had an unofficial position that favored condom use. One of the organizers of the AIDS program described these positions as such:

The first time that I heard [members of the Church] recommending condoms, they were people working with street children. In 88 , 89, on a program [on TV was] Dom Paulo. As they had agreed, the host asked "what were his recommendations for prevention, what should be done, include information, etc., and condom use, and such, right?" Dom Paulo did not use the word condom: "We have to support... blablabla... The Church is oriented towards supporting the sanitary authorities in the way presented by Dr. Pau- lo Teixeira..." [of the AIDS Program] ... I think in 92, the Youth Pastoral, according to the decision of the CNBB, adopted AIDS as an issue to be addressed together with the communities of youth. At the time, we did not have any possibility of supporting it financially, so it was a partnership that had more of a political character. (Public health physician)

Priests and bishops in other states, mean while, reinforced their canonical position, and emphasized the sinfulness of homosexuality, the value of monogamy and marital commitment, preaching abstinence and fidelity as the best way to prevent AIDS. Without support from Dom Paulo, the conflict was now in the open.

Many of those interviewed mentioned the controversy around the punishment of Father Valeriano, who announced the production of a video questioning the Vatican's position, which was undoubtedly against condoms. He was punished because in an interview in a daily newspaper, he defended the use and distribution of condoms. ${ }^{15}$ Several interviewees also recall that Dom Eugênio Sales (RJ) produced a note of repudiation, also signed by Dom Hummes, the new Cardinal-Archbishop of São Paulo, a reaction that was interpreted as an intervention coming directly from the Vatican and its "representatives and spies in Brazil". Informants said that in the Conference of Bishops they invited "someone from Rome" to speak about how the church was dealing with AIDS globally. In the words of a missionary priest:

He did not come solely for that purpose: he came to monitor a church in Brazil that was conveying the use of condoms. The cardinal of Rio de Janeiro, which we called a mobster of the Catholic Church here in Brazil, reported everything that happened here to Rome. So we prepared a pamphlet, the bishop was with us and took it to the directory of the CNBB to see if they appro-

15 This controversy reverberated in the Brazilian and foreign press, as illustrated in the reports of the Cafardo (2000), "Is Prete Difende" (2000), Jordan (2001) and "Religioso diz que CNBB" (2000). 
ved it. They approved it, and it was printed. When the person sent from Rome came, he ordered that we withdraw the pamphlet and asked the $C N B B$ to recant, because we said, "that was approved by the CNBB". The CNBB said that they had never seen the material and the bishop, who was following this work, sided with the CNBB. It was a disaster. (Missionary priest)

Activists from the NGO went to protest at the door of the house of the archbishop who accepted the commission, "and everything died there", said the interviewee. The commission that worked with the CNBB was undone and substituted "quietly by another commission that supported the Vatican". The public position, meanwhile, was less clear: "Rome did not want to lose its dialogue with governments" according to one priest interviewed, who explained that the Church feared the reaction to the debate opened by the media and preferred not to extend the controversy.

In 2003, in an "open letter" to the National STD/AIDS Program of the Ministry of Health, the presidency of the CNBB defends the Church' scare and support for the sick, in prevention initiatives and in combating prejudice suffered by those affected by the epidemic and disseminates its perspective on sexuality. It offers an alternative interpretation of technical-scientific thinking only on how to address prevention. Questioning the effectiveness of condoms and evoking the existence of other "effective methods", it defends a dogmatic moral order for educating youth, an "anthropology of sexuality" that fears comprehensive sexual education and adds that it would stimulate unlimited and irresponsible sexual behavior (CNBB, 2003).

From that moment on, several ecclesiastic authorities began to stimulate public controversies about the effectiveness of condom propagating that condoms form holes. A priest commented in an interview: "it forms less holes than the holes in monogamy and fidelity among couples". In spite of this, the unofficial response of base churches continued in São Paulo, defending the "Gospel of the good Samaritan", as an agent of the pastoral commented in his interview, insisting that it is the role of "every Christian, of every human being to give correct information and speak everything about AIDS. Everything! The priest is not there, the bishop is not there. You understand?" On the local level this work continued: "of clarification, of demanding politics that favor that education, that knowledge that can help people, especially for youth to protect itself, to have precaution". (Parish priest)

The National STD/AIDS Program, which was in line with the response in São Paulo since the 1990s (Berkman et al., 2005; Teixeira, 1997, 2003) enters the debate strongly. The most emblematic reaction was the "Campaign - Through condoms nothing passes", which shows a condom transformed into an aquarium with fish swimming, with the message "Use and trust it". ${ }^{16}$ Information and orientation was disseminated about condom safety and the correct way to use condoms consistently.

\section{Lessons from the Response to AIDS about Religious Coping}

The contribution of religious leaders in São Paulo to the successful social response to AIDS should not be ignored or seen as minimal. The history reported here is the version of the participants of this response articulated with government programs, a limitation of this study. In spite of this, the dynamics of religiosity and religious coping could also be described through the perspective of religious authorities, a coping style clearly affected by an institutional and political dimension, understandable only by going beyond the individual and strictly behavioral dimension. In other words, in this study we observed the influence of politics on religiosity and on the style of coping adopted (personal and institutional), which is shared among the religious followers.

16 This campaign can be found at: http://www.Aids. gov.br/campanha/carnaval-2004-pela-camisinhanao-passa-nada-use-e-confie (Accessed May 2012). 
In sum, since the 1980s, members of various religions as part of civil society contributed to the response in São Paulo with governmental programs dedicated to guaranteeing the right to integral health of people with HIV and to a form of prevention centered on condoms. That social movement was significant, as Correa (1997) discussed: denouncing governmental neglect, the sustainability of the protection of citizenship for people living with HIV, and the public debate about the importance of solidarity were always the role of civil society.

In their way, the religious people who participated in this study contributed to overcoming denial about the emergence of the epidemic since its first decade, when AIDS was most prevalent among homosexual men and drug users. They integrated what they learned into traditional religious discourse and their personal religiosity, transforming it when faced with an unexpected situation. In doing so, they challenged institutional religiosity and a style of coping that stimulated denial and the discrimination of the ill, which was the case of Catholics in São Paulo who lived with a strained internal debate, confronting isolation or punishment inflicted by the higher rungs of the Church's hierarchy aligned with the Vatican. The commitment of humanist-Catholics with diverse social movements, in synergy with Christians from several denominations inspired by Liberation Theology, constructed a style of religious coping that was necessarily collaborative - which was productive in responding to a critical and emerging epidemic. They distanced themselves from the majority of Christians, scientists and health professionals who acted based on their religiosity and morals, disregarding scientific evidence. ${ }^{17}$ These religious people promoted what we can consider a delegating style of coping: God would punish the promiscuous with AIDS and would save those who adhered to the morality proposed by canonic rules. "Bad behavior" produced infection and disease.

17 They disregarded even irrefutable epidemiological studies on the modes of transmission of the isolated virus.
Many Catholics, which during the first years of the epidemic participated in internal debates of the Church, remained for more than two decades assisting the so-called "ecclesiastic base communities" (base churches) and governmental AIDS programs. Others reconstructed "their mission", after dissidents were punished, distancing themselves from the conflictive official and institutional discourse of coping. As Perea (2004) noted, this was because they recognized themselves with the right to speak as individuals in the construction of everyday spaces and exercise their freedom of conscience.

\section{Like Vulnerability to IIIness, Religious Coping has Personal, Institutional and Socio-Political Dimensions}

The literature on coping takes into account the influence of culture and its power to mold the evaluation of situations, the systems of orientation of people around the world, as well as the power to prioritize which coping strategies to teach (Faria \& Seidl, 2005). Data from this study certainly confirmed these notions that to date have not been the focus of most studies on religious coping. Positioned in a human rights-based and a social constructionist perspective of social psychology of health (V. Paiva, 2012a, $2012 b$ ), this article aimed to expand this focus to include political and institutional dimensions that contextualize religious coping.

This study is in line with several scholars that observed how Brazilians cope with dogmatic regulation (Duarte, 2005; Duarte, Gomes, Jabor, \& Luna, 2006; Garcia et al., 2009; Martins, 2009). In other words, religious convictions take part in their decisions in the private sphere with reasonable autonomy against what doctrine dictates (Duarte, 2005; Duarte et al., 2006; Martins, 2009). Having different world views involved in rituals and beliefs, there fore, does not fully explain the behavior of members of religious groups, as discussed before (V. Paiva, Garcia, Santos, Terto, \& Munoz-Laboy, 2010).

If this phenomenon has been observed among the religious followers and adherents, the history of coping in the religious responses to AIDS presented in this article allows us to ob- 
serve what happens among religious authorities, clergy, and priests who, in turn, will produce the public discourses of coping that will be available for adherents in each religious tradition.

In this process, the actions of the "religious subject", as an agent of his personal religiosity and a historical actor, recreates the official discourse of the authority to make it more congruent with his/her own experience. This was also observed among Protestants by Watanabe (2005) and among youth from diverse religions by Silva, Santos, Carli and Paiva (2008). Not only do the choices and actions of religious authorities (e.g., priests, educators, reverends, pastors, deacons, Afro-Brazilian religious leaders) reflect their own cognitive and emotional subjectivities, as discussed in the literature on religious coping, but they also configure cultural meanings contextualized by social and political processes. The religiosity of these clergy and religious leaders active in their communities, who were key actors in the construction of a response to AIDS in São Paulo, as we saw, was marked by the socio-political context wherein the perspectives of humanism and of human rights was strengthened in governmental health programs allied with civil society.

There is thus no simple answer to the question of Defert (1996) presented in the introduction: should health professionals fear religious intervention or consider it an ally? The lesson that can be learned from this historical process is that health professionals should pay attention to religion in people's everyday lives, that is, to a religiosity that will be intersubjectively mobilized in each social and institutional context (community, programmatic, local, national, international). Taking into account the religiosity of adherents and followers in communities, schools, and the workplace where they promote health or social assistance is as important as the lived religiosity of religious leaders (i.e., not just their discourses about principles).

Although many religious leaders are politically and ethically led to represent tradition and dogma, sometimes at the expense of the human rights of people who are ill, the direct questioning of dogma by government agents leads to heated debates that do not usually result in mutual understanding, especially when sexuality is involved. This makes it difficult or even paralyzes health officials with the obligation to promote and protect the right to health of citizens of a secular state.

Lived religion, which is experienced in the everyday life of each person contextualized by the cultural and local political scenario, has been one way to address this deadlock. This perspective permits the interaction of clients, health workers, and religious authorities, whose religiosity is also the result of daily and intersubjective interactions (V. Paiva et al., 2010). As expressed in the narrative of one of the Catholic priests interviewed:

I always say: "I made a vow of chastity, it has been 28 years that I am priest, but if I do not renew my values of the Gospel (chastity, poverty, and so forth) everyday, the world will eat me alive". Because these values do not depend solely on the person, but this person lives within a world, within a society; and what for us are the values of the Gospel, for society they are not values. For society, she says: "I will have sex with one, two, or a thousand people, who cares; I will feel good, satisfied, and that's that'. Sowe must carry forward the discourses of these values while keeping your feet on the ground. And do not think that man, just because he was baptized, becomes holy. Or do not think that the day I was ordained a priest, I turned into an angel. (Missionary priest)

With similarities to religious traditions that are less centralized, one must thus distinguish, "the Catholic response" from the "response of the Catholic Church". Perea (2004) includes in the former actors within society that give meaning to Catholicism allied with human rights in the various aspects of life in which they are present; the latter implies the norms that were created and systematized through bureaucratic instances, which those interview called "canonic". Priest, archbishops, and chaplains that act with more open interpretations of rights, especially about sexual and reproductive rights, can make significant contributions, especially when 
the Church recognizes it has also been affected by AIDS (Transferetti, 2001, 2005).

In different contexts, in other countries, that do not have the same historical circumstances that beset the Brazilian "Catholic responses" (plural) to AIDS (to simultaneously confront dictatorship and have the debate about sanitary reform, or witness the production of a native theology, such as Liberation Theology) coping is also associated with the political vision of each religious mission (Seffner, Garcia, Muñoz-Laboy, \& Parker, 2011). Discourses and practices of a more canonist religiosity, which inspired a style of delegating coping, supported discrimination against people affected by the AIDS epidemic and increased individual and social vulnerability to illness. For example, they increase the vulnerability for infection of married women, and consequently of their children, trusting in the discourses of monogamy and fidelity of their husbands.

Every time they ask: are you for or against the use of condoms? There exist two ethics: one of principle and one of responsibility. The ethics of principle says that you should not drive on the wrong side of the road. But let's assume that in a moment of distraction you have not seen the sign, were distracted and did not notice and you came in, then you have the ethics of responsibility; you take care not to crash into another car, not to run over anybody, that is how the issue of condoms applies. (Activist from ecclesiastic base community who promotes condom use)

The psychosocial study of religious coping would benefit from addressing issues such as the relationship between sexuality and religion, which are directly related to AIDS, and are experienced in daily life. Religious persons in whatever position - as faithful followers or as part of the authority - are people affected by their socio-political and cultural contexts. A social psychology of religion that considers more significantly the historical construction of discourses might draw on shared cosmological symbols that resonate in daily life, giving meaning to the emotional and cognitive dimensions of coping and its styles, considering that religiosity and religious coping have personal and institutional dimensions, inextricably affected by their cultural and political contexts. The experiences of those who participated in the early response to AIDS in Brazil can provide a more informed practice of psychology.

\section{References}

Arquidiocese de São Paulo. (1990). Relatório Quinquenal 1985-1989: Vol. 6. São Paulo, SP: Autor.

Ayres, J. R. C. M., Paiva, V., \& França, I., Jr. (2010). From natural history of disease to vulnerability: Changing concepts and practices in contemporary public health. In R. Parker \& M. Sommer (Eds.), Routledge Handbook in Global Public Health (pp. 98-107). London: Routledge.

Ayres, J. R. C. M., Paiva, V., \& França, I., Jr. (2012). Conceitos e práticas de prevenção: Da história natural da doença ao quadro de vulnerabilidade e direitos humanos. In V. Paiva, J. R. Ayres, \& C. M. Buchalla (Orgs.), Vulnerabilidade e direitos humanos - Prevenção e promoção da saúde: Livro I. Da doença à cidadania (pp. 71-94). Curitiba, PR: Juruá.

Azevedo, D. (2004). A Igreja Católica e seu Papel Político no Brasil. Estudos Avançados, 18(54), 109-120.

Berkman, A., Garcia, J., Munoz-Laboy, M., Paiva, V., \& Parker, R. (2005). A critical analysis of the Brazilian response to HIV/AIDS: Lessons learned for controlling and mitigating the epidemic in developing countries. American Journal of Public Health, 95(7), 1162-1172.

Burawoy, M. (2009). The Extended Case Method: Four countries, four decades, four great transformations, and one theoretical tradition. London: University of California Press.

Burdick, J. (1996). Looking for God in Brazil: The progressive Catholic Church in urban Brazil's religious arena. Berkeley, CA: University of California Press.

Cafardo, R. (2000, 7 jul.). Ato em SP apóia padre pró-camisinha. Estadão. Recuperado em 7 de julho de 2000, de http://www.estadao.com.br/agestado/nacional $/ 2000 / j u l / 07 / 276$.htm

Centro de Referência Técnica em Psicologia e Políticas Públicas. (2008). Referências técnicas para a atuação do(a) psicólogo(a) nos Programas de DST e AIDS. Brasília, DF: Conselho Federal de Psicologia. 
Centro de Referência Técnica em Psicologia e Políticas Públicas. (2009). Práticas Emergentes e Inovadoras de psicólogos(as) no campo das DST/ AIDS: Vol. 1. Práticas em Psicologia e Políticas Públicas. Brasília, DF: Conselho Federal de Psicologia.

Chesnut, R. A. (1997). Born again in Brazil: The Pentecostal boom and the pathogens of poverty. Piscataway, NJ: Rutgers University Press.

Coates, T., Temoshok, L., \& Mandel, J. (1984). Psychosocial research is essential to understanding and treating AIDS. American Psychologist, $39,1309-1314$.

Conferência Nacional dos Bispos do Brasil. (2003, 09 dez.). Declaração da Presidência da CNBB sobre a "Carta aberta" do Programa Nacional de DST e Aids, do Ministério da Saúde. Recuperado em 22 de abril, 2013, de http://www.zenit. org/pt/articles/declaracao-do-episcopado-brasileiro-sobre-carta-aberta-do-programa-nacional-de-dst-e-aids

Correa, S. (1997). A solidariedade como solução. Boletim da ABIA - Associação Brasileira Interdisciplinar de AIDS, 37.

Defert, D. (1996). AIDS as a challenge to religion. In J. Mann \& D. J. M. Tarantola (Eds.), Aids in the world II (pp. 447-452). New York: Oxford University Press.

Duarte, L. F. D. (2005). Ethos privado e justificação religiosa: Negociações da reprodução na sociedade brasileira. In M. L. Heilborn, L. F. D. Duarte, C. Peixoto, \& M. L. Barros (Orgs.), Sexualidade, familia e ethos religioso (pp. 137-176) Rio de Janeiro, RJ: Garamond Universitária.

Duarte, L. F. D., Gomes, E. C., Jabor, J., \& Luna, N. (2006). Família, reprodução e ethos religioso: Subjetivismo e naturalismo como valores estruturantes. In L. F. D. Duarte, M. L. Heilborn, M. L. Barros, \& C. Peixoto (Orgs.), Família e religião, (pp. 15-25). Rio de Janeiro, RJ: Contra Capa.

Faria, J. B., \& Siedl, E. M. F. (2005). Religiosidade e enfrentamento em contextos de saúde e doença. Revisão de literatura. Psicologia: Reflexão e Critica, 18(3), 381-389.

Farmer, P. (1999). Pathologies of power: Rethinking health and human rights. American Journal of Public Health, 89, 1486-1496.

Galvão, J. (1997). As respostas religiosas frente à epidemia de HIV/AIDS no Brasil. In R. Parker
(Org.), Politicas, instituições e aids: Enfrentando a epidemia no Brasil (pp. 109-134). Rio de janeiro, RJ: Jorge Zahar.

Garcia, J., Muñoz-Laboy, M., Almeida, V. de, \& Parker, R. (2009). Local impacts of religious discourses on rights to express same-sex sexual desires in periurban Rio de Janeiro. Sexuality Research and Social Policy, 6(3), 44-60.

Garcia, J., Muñoz-Laboy, M., \& Parker, R. (2011). Vulnerable salvation: Evangelical Protestant leaders and institutions, drug use and HIV and AIDS in the urban periphery of Rio de Janeiro. Global Public Health, 6(Suppl. 2), S243-S256.

Garcia, J., \& Parker, R. G. (2011). Resource mobilization for health advocacy: Afro-Brazilian religious organizations and HIV prevention and control. Social Science \& Medicine, 72(12), 1930-1938.

Garrido, P. B., Paiva, V., Nascimento, V., Souza, J. B., \& Santos, N. (2007). Aids, estigma e desemprego: Implicações para os serviços de saúde. Revista de Saúde Pública, 41(Supl. 1), 72-79.

Gaspari, E. (2002). A ditadura escancarada. São Paulo, SP: Cia das Letras.

Gough, B. (2007). Coming out in the heterosexist world of sport: A qualitative analysis of web postings by Gay athletes. Journal of Gay and Lesbian Psychotherapy, 11(1-2), 153-174.

Govender, K. (2011). The cool, the bad, the ugly, and the powerful: Identity struggles in schoolboy peer culture. Culture, health \& Sexuality, 13(8), 887-901.

Gruskin, S., \& Tarantola, D. (2008). Health and human rights: Overview. In K. Heggenhougen \& S. Quah (Eds.), International Encyclopedia of Public Health (Vol. 3, pp. 137-146). San Diego, CA: Elsevier.

Gruskin, S., \& Tarantola, D. (2012). Um panorama sobre saúde e direitos humanos. In V. Paiva, J. R. Ayres, \& C. M. Buchalla (Orgs.), Vulnerabilidade e Direitos Humanos. Prevenção e Promoção da Saúde: Vol. 1. Da doença à cidadania (pp. 23-42). Curitiba, PR: Juruá.

Is prete difende i preservativi la chies alo punisce. (2000, 5 di luglio). CNN Italia. Retrieved September 12, 2000, from http://www.cnnitalia. it/2000/MONDO/amerlatina/07/04/prete/

Jordan, M. (2001, February 21). Brazil's unconventional AIDS fight. The Wall Street Journal, p. I-IV. 
Kian, E. M., \& Anderson, E. (2009). John Amaechi: Changing the way sport reporters examine Gay athletes. Journal of Homosexuality, 56(7), 799818. doi: 10.1080/00918360903187788

Mann, J., \& Tarantola, D. J. M. (Eds.). (1996). Aids in the world II. New York: Oxford University Press.

Martins, A. D. (2009). Catolicismo contemporâneo: Tratando da diversidade. In E. C. Gomes (Org.), Dinâmicas contemporâneas de fenômeno religioso na sociedade brasileira (pp. 125-146). Aparecida, SP: Ideias e Letras.

Mott, L. (1985). Aids: Reflexão sobre sodomia. Comunicações do ISER, 17, 32-41.

Murray, L. R., Garcia, J., Muñoz-Laboy, M., \& Parker, R. G. (2011). Strange bedfellows: The Catholic Church and Brazilian National AIDS Program in the response to HIV/AIDS in Brazil. Social Science \& Medicine, 72(6), 945-952.

Paiva, G. J. (1998). AIDS, Psicologia e religião: O estado da questão na literatura psicológica. $P s i$ cologia: Teoria e Pesquisa, 14(1), 27-34.

Paiva, G. J., Zangari,W., Verdade, M. M., Machado de Paula, J. R., Faria, D. G. R., Gomes, D. M., ...Gomes, A. M. A. (2009, jul./set.). A Psicologia da Religião no Brasil. Psicologia: Teoria e Pesquisa, 25(3), 441-446.

Paiva, V. (2008). A psicologia redescobrirá a sexualidade? Psicologia em Estudo, 13, 641-651.

Paiva, V. (2012a). A dimensão psicossocial do cuidado. . In V. Paiva, J. R. Ayres, \& C. M. Buchalla (Orgs.), Vulnerabilidade e Direitos Humanos. Prevenção e Promoção da Saúde: Vol. 2. Entre individuos e comunidade (2. ed., pp. 41-72). Curitiba, PE: Juruá.

Paiva, V. (2012b). Cenas da vida cotidiana: metodologia para compreender e reduzir a vulnerabilidade na perspectiva dos direitos humanos. In $\mathrm{V}$. Paiva, J. R. Ayres, \& C. M. Buchalla (Orgs.), Vulnerabilidade e Direitos Humanos. Prevenção e Promoção da Saúde: Vol. 1. Da doença à cidadania (pp. 23-42). Curitiba, PR: Juruá.

Paiva, V., Aranha, F., Bastos, F. I. P. M., \& Grupo de Estudos em População, Sexualidade e Aids. (2008). Opiniões e atitudes em relação à sexualidade: Pesquisa nacional brasileira. Revista de Saúde Pública, 42, 54-64.

Paiva, V., Garcia, J., Santos, A. De O., Terto, V., Jr., $\&$ Munoz-Laboy, M. (2010). Religious communities and HIV prevention: An intervention-stu- dy using human rights based approach. Global Public Health, 5, 280-294.

Paiva, V., \& Zucchi, E. (2012). Estigma, discriminação e saúde: Aprendizado de conceitos e práticas no contexto da epidemia de HIV/Aids. In V. Paiva, J. R. Ayres, \& C. M. Buchalla (Orgs.), Vulnerabilidade e Direitos Humanos. Prevenção e Promoção da Saúde: Vol. 1. Da doença a cidadania (pp. 111-144). Curitiba, PR: Juruá.

Parker, R., \& Aggleton, P. (2001). Estigma, discriminação e AIDS: Vol. 1. Coleção Cidadania e direitos. Rio de Janeiro, RJ: Associação Brasileira Interdisciplinar de AIDS.

Parker, R., \& Aggleton, P. (2003). HIV and AIDS related stigma and discrimination: A conceptual framework and implications for action. Social Science \& Medicine, 57, 13-24.

Parker, R., Garcia, J., \& Muñoz-Laboy, M. (2013). Sexual Social Movements and Communities. In D. L. Tolman \& L. Diamond (Eds.), The American Psychological Association's Handbook of Sexuality and Psychology. Washington, DC: American Psychological Association.

Perea, J. G. F. (2004). Tres reflexiones sobre la sexualidad y los derechos humanos en el ámbito de la Iglesia católica. Estudios Demográficos y Urbanos, 57, 639-686.

Peres, J. F. P., Simão, M. J. P., \& Noasello, A. G. (2007). Espiritualidade, religiosidade e psicoterapia. Revista de Psiquiatria Clínica, 34(Suppl. 1), 136-145. Recuperado em 27 de março, 2012, de SciELO.

Perucchi, J., Rodrigues, F. D., Jardim, L. N., \& Calais, L. B. (2011). Psicologia e Políticas Públicas em HIV/AIDS: Algumas reflexões. Psicologia \& Sociedade, 23, 72-80.

Pollozi, L., \& Souza, C. A. M. (Orgs.). (2001). Franco Montoro, humanismo e politica. São Paulo, SP: Edições Loyola.

Religioso diz que CNBB só condena preservativo por pressão da Santa Sé. (2000, 26 jun.). Folha de São Paulo.

Sampaio, J., \& Araújo, J. L., Jr. (2006). A relevância dos aspectos sócio-culturais para as políticas públicas de prevenção em AIDS. Psicologia Política, 6(11), 83-106.

Sanchez, Z. V. D. M., \& Nappo, S. A. (2008). Religious treatments for drug addiction: An exploratory study in Brazil. Social Science \& Medicine, 67, 638-646. 
Seffner, F., Garcia, J., Muñoz-Laboy, M., \& Parker, R. (2011). A time for dogma, a time for the Bible, a time for condoms: Building a Catholic theology of prevention in the face of public health policies at Casa Fonte Colombo in Porto Alegre, Brazil. Global public health, 6(sup2), S271$-\mathrm{S} 283$.

Seffner, F., Gonçalves, C. M., Maksud, I., Garcia, J., Rios, L. F, Natividade, M., ...Parker, R. (2008). Respostas religiosas à Aids no Brasil: Impressões de pesquisa acerca da pastoral de DST/Aids da igreja católica. Ciências Sociais e Religião, 10(10), 159.

Silva, C. G., Santos, A. O., Carli, D., \& Paiva, V. (2008, out./dez.). Religiosidade, juventude e sexualidade: Entre a autonomia e a rigidez. Psicologia em Estudo, 13(4), 683-692

Souza, P. O., Santos, N., Almeida, V., \& Paiva, V. (2012). O trabalho colaborativo com comunidades religiosas para a prevenção do HIV/Aids: A experiência do GT-Religiões em São Paulo. In V. Paiva, J. R. Ayres, \& C. M. Buchalla (Orgs.), Vulnerabilidade e Direitos Humanos: Vol. 1. Prevenção e Promoção da Saúde (pp. 239-271). Curitiba, PR: Juruá.

Teixeira, P. R. (1997). Políticas públicas em AIDS. In R. Parker, Políticas, instituições e AIDS: Enfrentando a epidemia no Brasil. Rio de janeiro, RJ: Associação Brasileira Interdisciplinar de AIDS.
Teixeira, P. R. (2003). Universal access to AIDS medicines: The Brazilian experience. Divulgação em Saúde para Debate, 27, 184-191.

Transferetti, J. (2001). Pastoral da Família e AIDS: Comunicação, saúde e conscientização. São Paulo, SP: Átomo.

Transferetti, J. (2005). CNBB, AIDS e Governo: Tarefas para uma teologia da prevenção. Campinas, SP: Átomo.

Vasconcellos, E. G. (1992). Aids e a morte psicossomática. In V. S. F. Paiva \& L. B. N. Alonso Fernandes (Orgs.), Em tempos da AIDS (pp. 32-37). São Paulo, SP: Summus.

Watanabe, T. H. B. (2005). Caminhos e histórias: A historiografia do protestantismo na Igreja Presbiteriana do Brasil. Revista de Estudos da Religião, 1, 15-30.

Zurba, M. C. (2011). Contribuições da Psicologia Social para o psicólogo na saúde coletiva. Psicologia \& Sociedade, 23, 5-11.

Recebido: $19 / 07 / 2012$ Aceite final: 29/08/2012 